\title{
The COVID-19 Pandemic: Theories to Therapies
}

\author{
Sefali Acharya $(1)$ \\ Dover, New Hampshire, USA \\ Email: sefaliacharya@gmail.com
}

How to cite this paper: Acharya, S. (2020) The COVID-19 Pandemic: Theories to Therapies. Advances in Infectious Diseases, 10, 16-28

https://doi.org/10.4236/aid.2020.103003

Received: April 28, 2020

Accepted: May 24, 2020

Published: May 27, 2020

Copyright (c) 2020 by author(s) and Scientific Research Publishing Inc. This work is licensed under the Creative Commons Attribution International License (CC BY 4.0).

http://creativecommons.org/licenses/by/4.0/

Open Access

\begin{abstract}
Present COVID-19 pandemic has confronted almost every sector of the world creating terrible havoc and impacting day to day life of each individual. Severe Acute Respiratory Syndrome Coronavirus 2 (SARS-CoV2), identified and reported in Wuhan city, China spread across the globe with an unseen and unpredictable trajectory and limited knowledge of pathogenicity and epidemiology. With the major challenge lying in treatment and vaccine development, researchers and health care workers have come upfront to contribute in terms of knowledge and support. This review presents an overview of the structure, multiplication, and uniqueness of the novel coronavirus focusing on the ongoing treatments and scope of vaccines based on the current studies available in the literature.
\end{abstract}

\section{Keywords}

Infectious Disease, Coronavirus, Pandemic, Vaccine

\section{Introduction}

Time and again there are reports of new viruses emerging, be it a new species from the laboratory (H1N1) or new viruses discovered or transmitted from animals (MERS, SARS). Table 1 represents the worst events of pandemic in history to date. The recent outbreak of coronavirus (corona in Latin means crown) is one such example, reported in Wuhan city, Hubei Province, China in December 2019 [1] [2]. Epidemiological reports suggest that the Wuhan virus, as largely said was associated with a Huanan seafood market in Wuhan. The very first case reported (a 41-year-old worker at the seafood market) was admitted to hospital on Dec 12, 2019, with a complaint of unproductive cough, fever, weakness, and chest ache. Meta-transcriptomic sequencing of bronchoalveolar lavage (BAL) fluid from another patient revealed the presence of a novel single stranded RNA virus strain (29,903 nucleotides) from the family Coronaviridae [3]. Since then, 
the virus is known to have multiple names like SARS-CoV-2 [4] and HCoV-19 [5] and the outbreak as COVID-19 (coronavirus disease 2019). Phylogenetic analysis of whole genome ( $29.9 \mathrm{~kb})$ revealed that the novel virus is strikingly similar to a SARS-like coronavirus with a percentage match of 89.1 [3] indicating a zoonotic transfer from animal precisely bats sold at the wet market in Wuhan (Figure 1(a) and Figure 1(b)). But the fact that there were no bats present in the Huanan seafood market is drawing the attention of several researchers hinting at the virus to be lab-made.

Also, to substantiate, there are some reports claiming patients as early as November $17^{\text {th }}$ (which needs validation) and December $1^{\text {st }}$ which had no direct connection to the wet market, and no epidemiologist link to the later cases [6]. Investigations are ongoing throughout the world to trace the actual time of origin and its spread. As of now, there has been a report of 4 million cases of infection and 280,965 deaths in this global pandemic affecting 211 countries within four months. Current review provides an insight into the origin of the novel coronavirus-SARS-CoV2 and its distinctive features highlighting the multiplication and phenomenal spread.

\section{Theories of Origin}

All the coronaviruses infecting humans have animal origins like bats, rodents, or camels. The last outbreak of SARS in 2002-03 and MERS in 2012 are the results of zoonotic transfers across the species barrier which were considered highly

Table 1. Representing major pandemic outbreaks in the history.

\begin{tabular}{|c|c|c|c|c|c|c|c|c|c|}
\hline Name & Major Symptoms & $\begin{array}{c}\text { First } \\
\text { Detection }\end{array}$ & $\begin{array}{l}\text { Global } \\
\text { Cases }\end{array}$ & $\begin{array}{c}\text { Global } \\
\text { Death Rate }\end{array}$ & Transmission & Affected groups & Treatments & Vaccines & $\begin{array}{c}\text { End of } \\
\text { Pandemic }\end{array}$ \\
\hline $\begin{array}{c}1918 \\
\text { Influenza }\end{array}$ & $\begin{array}{c}\text { fever, nausea, } \\
\text { aches, diarrhea }\end{array}$ & $\begin{array}{l}\text { March 1918, } \\
\text { NA }\end{array}$ & $\begin{array}{l}500 \\
\text { million }\end{array}$ & nearly $2 \%$ & $\begin{array}{l}\text { respiratory } \\
\text { droplets }\end{array}$ & ages $20-40$ & none & none & $\begin{array}{c}\text { summer } \\
1919\end{array}$ \\
\hline $\begin{array}{l}\text { Seasonal } \\
\text { Flu }\end{array}$ & $\begin{array}{c}\text { fever, sore throat, } \\
\text { cough, fatigue }\end{array}$ & NA & 1 billion & $0.10 \%$ & $\begin{array}{l}\text { respiratory } \\
\text { droplets }\end{array}$ & $\begin{array}{l}\text { older adults and } \\
\text { immuno-compro } \\
\text { mised }\end{array}$ & $\begin{array}{l}\text { Tamiflu, } \\
\text { Relenza, } \\
\text { Rapivab, } \\
\text { Xofluza }\end{array}$ & available & NA \\
\hline $\begin{array}{c}\text { 2002-2004 } \\
\text { SARS }\end{array}$ & $\begin{array}{l}\text { fever, cough, } \\
\text { malaise }\end{array}$ & $\begin{array}{l}\text { November } \\
\text { 2002, China }\end{array}$ & 8098 & $15 \%$ & $\begin{array}{l}\text { respiratory } \\
\text { droplets and } \\
\text { contaminated } \\
\text { surfaces }\end{array}$ & $\begin{array}{c}\text { older } \\
\text { individual }>60 \\
\text { had higher death } \\
\text { rate }\end{array}$ & $\begin{array}{c}\text { antivirals } \\
\text { and steroids }\end{array}$ & available & July 2003 \\
\hline $\begin{array}{l}\text { H1N1 Flu } \\
\text { Pandemic }\end{array}$ & $\begin{array}{c}\text { fever, chills, } \\
\text { cough, body ache }\end{array}$ & $\begin{array}{l}\text { 2009, Mexico } \\
\text { and US }\end{array}$ & $\begin{array}{c}60.8 \\
\text { million } \\
\text { U.S cases }\end{array}$ & $0.02 \%$ & $\begin{array}{l}\text { respiratory } \\
\text { droplets }\end{array}$ & $\begin{array}{l}\text { children between } \\
5-19\end{array}$ & antivirals & available & $\begin{array}{l}\text { August } \\
2010\end{array}$ \\
\hline Ebola & $\begin{array}{c}\text { fever, aches, pain, } \\
\text { diarrhea, } \\
\text { weakness, } \\
\text { vomiting }\end{array}$ & 2013, Guinea & 28,652 & $50 \%$ & $\begin{array}{l}\text { bodily fluids like } \\
\text { blood, sweat, } \\
\text { feces and close } \\
\text { contact }\end{array}$ & children & none & none & $\begin{array}{l}\text { March } \\
2016\end{array}$ \\
\hline COVID-19 & $\begin{array}{l}\text { unproductive } \\
\text { cough, fever, } \\
\text { shortness of } \\
\text { breath, headache }\end{array}$ & $\begin{array}{l}\text { December } \\
\text { 2019, China }\end{array}$ & $\begin{array}{l}\quad>4 \\
\text { million }\end{array}$ & $3.40 \%$ & $\begin{array}{c}\text { unproductive } \\
\text { cough, fever, } \\
\text { shortness of } \\
\text { breath, headache }\end{array}$ & $\begin{array}{l}\text { adults over } 60 \\
\text { and with } \\
\text { underlying health } \\
\text { conditions }\end{array}$ & none & none & NA \\
\hline
\end{tabular}


(a)
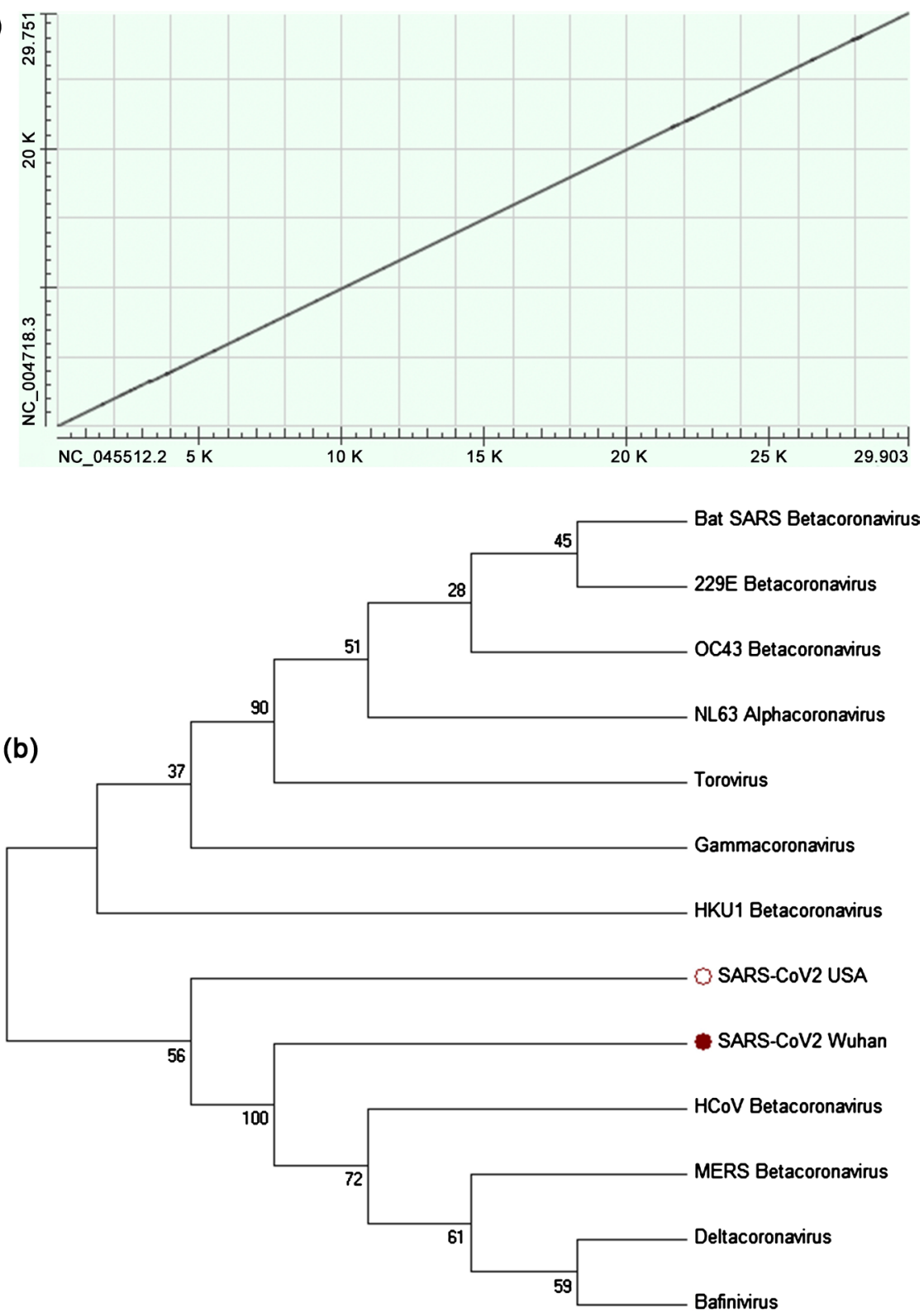

Figure 1. Dot Blast between novel coronavirus (NC_045512.2) and existing SARS-like coronavirus (NC_0047183) showing 89.1\% match (Source: NCBI). (b) Maximum Parsimony analysis of taxa using MEGA6 software positions SARS-CoV2 very closely to the human coronaviruses. The bootstrap consensus tree inferred from 100 replicates is taken to represent the evolutionary history of the taxa analyzed. Branches corresponding to partitions reproduced in less than $50 \%$ bootstrap replicates are collapsed.

pathogenic. Some theories suggest natural selection in humans [7] and the other way as natural selection in animals before zoonotic transfer with respect to the origin of novel coronavirus [8]. SARS-CoV2 is thought to be originated from bat with an intermediate host-pangolin before infecting humans [8]. Although genomic features of SARS-CoV are identical to Rhinolophus affinis (bat), the differences lie in the viral binding sites that share close similarity with the Malayan pangolins (Manis javanica) indicating a natural selection before human trans- 
mission [9]. With a common ancestor and an intermediate host, the chances are high that the SARS-CoV2 might have jumped to humans and prevailing in there before infecting a cluster [9]. Since the 2002-03 SARS outbreak, research on coronaviruses has drastically increased. There are reports of laboratory escape of SARS-CoV that might be another angle to look at [10]. More research and scientific transparency in this field is the need of the hour.

\section{Classification and Structure of Coronavirus}

Coronavirus belongs to the order Nidovirales and family Coronaviridae that divides into two sub-family namely Coronavirinae and Torovirinae. The Coronavirinae is further divided into a group of four-alpha, beta, gamma, and delta. SARS-CoV2, a beta coronavirus is the seventh known coronavirus that infects humans and causes severe pneumonia-like disease along with SARS-CoV and MERS-CoV (Figure 2). The alpha coronaviruses like HCoV-229E and HCoVNL63 are known to show only minimal symptoms in humans [11].

All the viruses classified under this order are enveloped and have a positive non-segmented RNA genome of $\sim 30 \mathrm{~kb}$. The presence of $5^{\prime}$ cap structure and poly A tail allows the virus to act like mRNA for translation. The genome organization of coronavirus is described as 5'-UTR-replicase-Spike (S)-Envelope (E)Membrane (M)-Nucleocapsid (N)-3'UTR-polyA tail (Figure 3). Structural proteins are essential for infection and viral assembly whereas genes coding for non-structural proteins seems to have a minor role in the replication in tissue culture while some have very important roles in pathogenesis [12] [13]. The spike comprises of two subunits-S1 and S2 which is 1285 amino acids long [9]. The receptor binding domain (RBD) is located in the S1 subunit that binds to ACE2 (angiotensin-converting enzyme 2) of human cells and triggers a cascade of inflammation in the respiratory tract [13] [14] [15]. ACE2 is an ectoenzyme that converts angiotension II to angiotension $1-7$, a key regulator of blood pressure angiotensin-converting enzyme [16].

\section{What's New in SARS-CoV2?}

The densely glycosylated spike protein is a fusion protein (trimeric class I) that

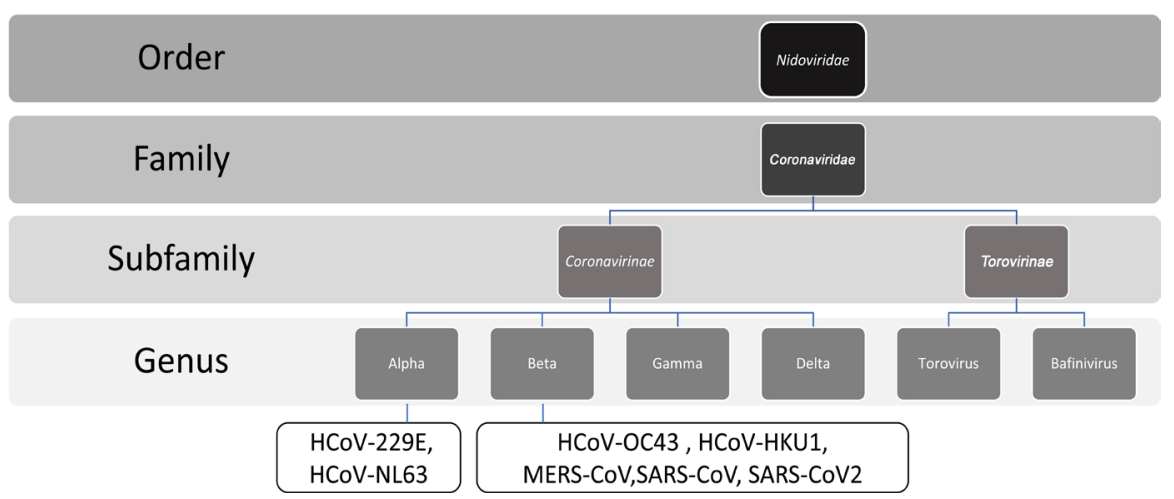

Figure 2. Classification of coronavirus. 
(a)

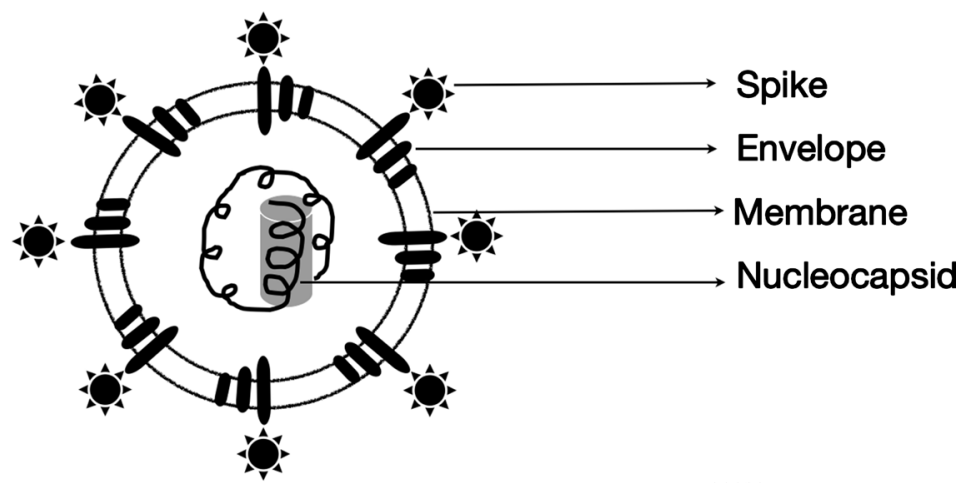

(b)

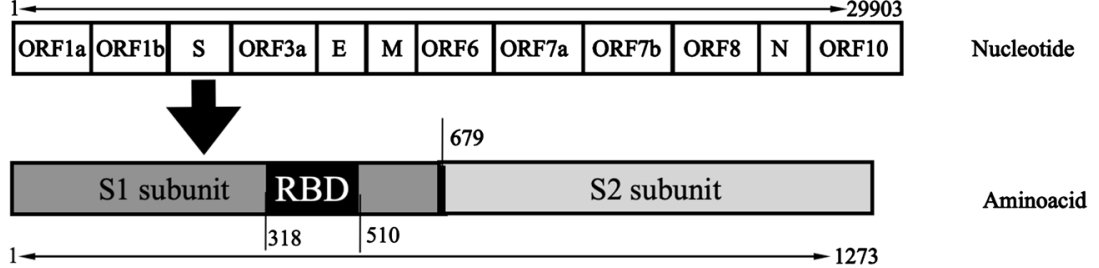

Figure 3. Structure (a), genetic organization (b), and corresponding peptide sequence (c) of coronavirus.

changes its confrontation and undergoes a structural rearrangement to enter into the target cell. The entire process begins when the S1 subunit binds to the receptor which leads to its destabilization and shedding of the subunit. This lets the stabilization of S2 subunit post fusion. According to Wrapp et al., these two states are referred to as "down and up" confrontation, where down is the receptor remote state and the later referred to as receptor ready state which is comparatively less stable. Biophysical assays made by Wrapp et al., indicates that the spike protein binds to the host cell ten times stronger than other SARS viruses. Maybe that's the reason the SARS-CoV2 spreads so fast from person to person through respiratory transmission. The spike protein hence is the potential candidate for vaccine design and development [17]. The RBD essentially is the key element for binding and is the most adaptable fragment of the coronavirus family. Five out of six critical amino acids seemed to be different than the existing SARS-CoV that results in the high affinity binding to the host cell receptor [9]. Anderson et al., suggests the presence of polybasic cleavage site at S1/S2 junction allowing proper cleavage by proteases thereby indicating superior host selection and infection [9].

\section{Entry and Replication of Coronaviruses}

As the spike protein binds to the ACE2 receptor of the target cell, it unlocks its way into the host cell cytoplasm (Figure 4). The entry into the host cell is facilitated when TMPRSS2 (type 2 transmembrane protease) chops off the ACE2 thereby activating the spike protein, a mechanism followed by the influenza virus [18].

After entry, the virus unwraps the envelope or the E protein, thereby letting the nuclear content or the genomic RNA release in the cytosol. The ORF1a and 


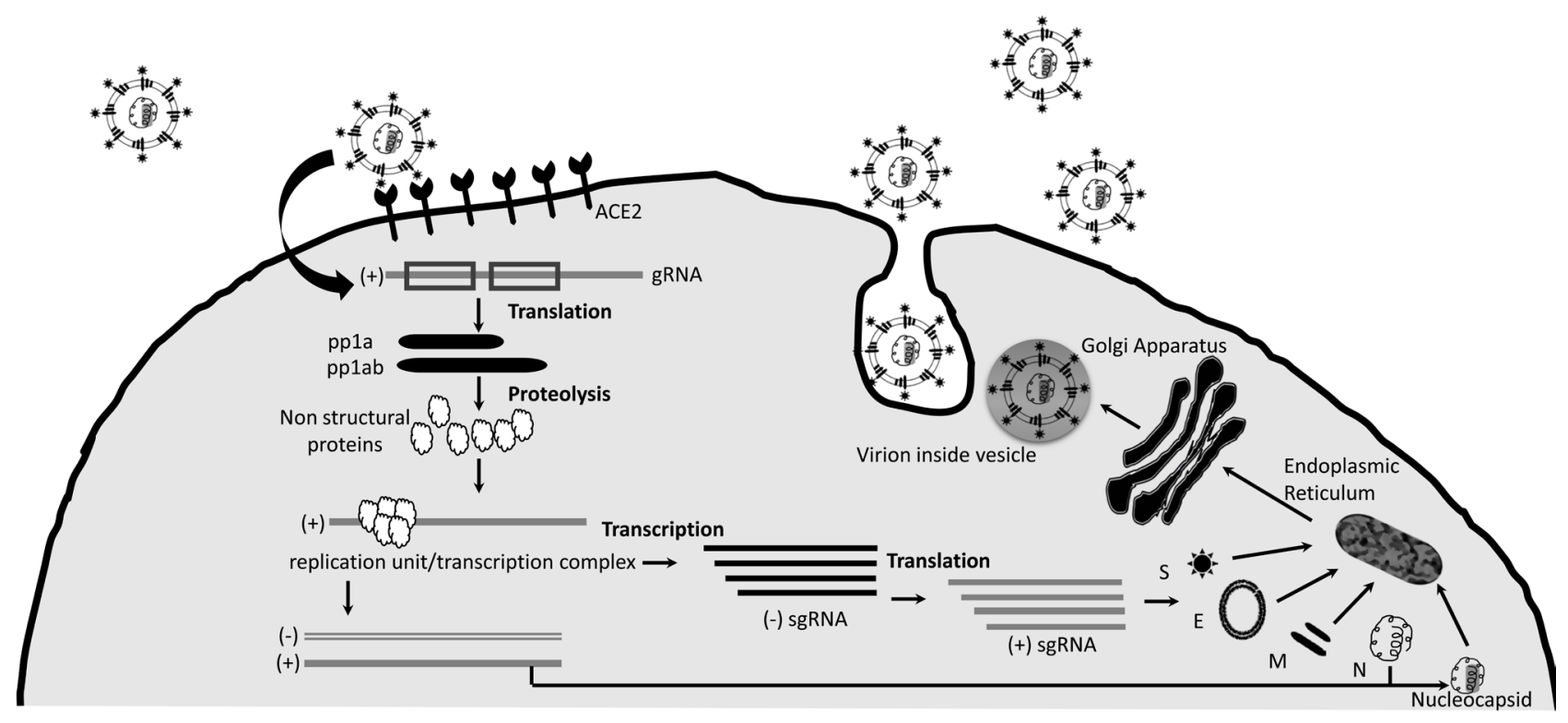

Figure 4. Schematic representation of virus entry and release in the host cytoplasm.

ORF1b translate into ppla and pplab proteins respectively. Proteases cleave of these proteins to generate 16 non-structural proteins essential for new virus assembly. Some of them form transcription complex/replication unit-RNA-dependent RNA polymerase, RdRp, that uses the [+] strand gRNA as the template to make copies. The replicated [+] strand is now the genome of a new virus particle. Subgenomic RNAs are translated into structural proteins-S, E, M, and N proteins that form the viral particle out of which the first three enters the endoplasmic reticulum (ER) and the last one, with the $[+]$ strand gRNA becomes a nucleoprotein complex. Inside the ER-Golgi apparatus complex, the proteins amalgamate into a new virus unit which then is excreted out to the extracellular space with the help of vesicle (Figure 4).

\section{Pathogenicity, Incubation Period and Transmission Rate of COVID-19}

The pandemic has taken over two hundred thousand lives affecting almost every part of the globe. New cases and causalities are reported every day and still, there is no sign of relief. SARS-CoV2 that causes atypical pneumonia-like disease and sometimes acute respiratory distress syndrome (ARDS) especially in the lower respiratory tract binds to the ACE2 receptor of host cells resulting in rapid respiratory failure. These receptors are present in the epithelial cells of the upper respiratory tract, alveoli, trachea, bronchi and bronchial serous glands [19] as well as macrophages and alveolar monocytes. They serve as the primary target where the virus enters, replicate, and release in huge numbers. The presence of ACE2 in endothelial cells of arteries and veins, mucosal linings of the intestines, epithelial cells of the kidney and renal tubes, and immune cells make them secondary target infecting almost the entire body. That is the reason a person is completely isolated as there are high chances of presence of virions in patients' 
saliva, sweat, urine, and stool.

The presence of ACE2 is still not the determining factor of vulnerability, though it can be speculated that higher the receptor higher the risk factor. Studies have confirmed the involvement of ACE2 in diabetes, cardiac function, and hypertension [20] [21] [22]. Hence, people associated with any of these ailments fall into the category of serious illness and death. Elderly people are also at elevated risk because of a reduced immune response, multiple prevailing diseases, and altered physiological changes associated with aging. But the norm "only elderly people are at high risk" is solely wrong. As per WHO, 10\% - 15\% of cases reported are under the age of 50 and have moderate to very severe infection leading to death. Statistics suggest that the COVID-19 has a brief incubation period but a lengthier clinical course as patients take a long time to either recover or die [23]. It is estimated that the median incubation period for this virus is around 5.1 days [24]. That means it is mostly the $5^{\text {th }}$ day when a person with coronavirus infection starts to show symptoms after exposure, in other words, it become symptomatic. Though, the range varies from day 1 to day 14 . Other respiratory illnesses caused by the coronavirus family also have a similar incubation period-SARS has a mean of 5 days with range 2 to 14 days [25]. Similarly, MERS [26] has a mean of 5 to 7 days and range 2 to 14 days whereas, non-SARS human coronavirus has a mean of 3 days ranging from 2 to 5 days [27]. Preliminary analysis suggests that the transmission rate or the reproduction number stated as $\mathrm{R}_{0}$ (R naught) in SARS-CoV2 is around 2.24 - 3.58 which means a single infected person can infect $2-4$ people. Whereas in the case of SARS ( 1 - 2.75) and MERS (>1), $\mathrm{R}_{0}$ is comparatively low [18] [28]. It is very important to have the exact knowledge of the incubation period and the rate of transmission to slow down the spread and also to safeguard the use of protective gear in the hospitals amidst the acute shortage.

\section{Treatments}

With the exponential increase of cases and causalities every day, researchers and health officials are trying their best to cope and come up with a possible "treatment". Right now, the best treatment offered is care and intensive support. Preventing the transmission and slowing down the spread by social distancing are the two major goals that are put forth. Clinicians are applying what they know from previous endemics like SARS, MERS, and Ebola. Though similar, COVID19 is quite different from the previous diseases, hence treating a new disease with old medicine is not giving a satisfactory response. Table 2 shows the current list of medications that is categorized into host cell based and virus-based delivery. Drugs from various classes like nucleoside analogs, protease inhibitors, hosttargeted, and interferons have been tested for the treatment of COVID-19 out of some are already in clinical trials [29].

\subsection{Nucleoside Analogs}

Nucleoside analog target RNA-dependent RNA polymerase to inhibit replication 
Table 2. List of medication in current use for the treatment of COVID-19.

\begin{tabular}{|c|c|}
\hline Drugs & Mechanism of action \\
\hline \multicolumn{2}{|l|}{ Virus-based approaches } \\
\hline Remdesvir & Terminates premature viral chain \\
\hline Galidesvir & Terminates premature viral chain \\
\hline Favipiravir & Inhibits RdRp \\
\hline Ribavirin & Inhibits viral RNA synthesis \\
\hline Penciclovir & Inhibits RdRp \\
\hline Nafamostat & Inhibits entry \\
\hline Griffithsin & Inhibits entry \\
\hline Lopinavir & Decreases viral load \\
\hline Ritonavir & Increases the bio-availability of ritonavir \\
\hline Darunavir & Prevents viral replication \\
\hline camostat mesylate & Blocks TMPRSS2 \\
\hline ASC09F & Decreases viral load \\
\hline \multicolumn{2}{|l|}{ Host-based approaches } \\
\hline Recombinant interferons & Exogenous interferons \\
\hline Chloroquine & Blocks viral entry \\
\hline Nitazoxanide & Induces host innate immune response \\
\hline Tocilizumab & Suppresses host immunity \\
\hline Interferon-I & Modulates immune response \\
\hline Glucocorticoids & Inhibit cytokine production \\
\hline
\end{tabular}

in broad-spectrum of viruses. Remdesivir and galidesivir, two experimental adenosine analog that leads to pre-mature termination of viral chains thereby inhibiting RNA synthesis demonstrates antiviral activity [30]. Remdesivir which is under clinical development for the treatment of Ebola is showing promising results. Studies confirm that remdesivir is effective in the control of SARS-CoV2 infection in vitro. National Institute of Health (NIH) has already started clinical trials to treat COVID-19. Ribavirin and favipiravir, two approved drugs for hepatitis C virus (HCV) and respiratory syncytial virus (RSV) were evaluated against SARS-CoV2 but the efficacy is uncertain.

\subsection{Protease Inhibitors}

Lopinavir and ritonavir having antiviral activity against human coronaviruses are used as a combination drug for the treatment of human immunodeficiency virus (HIV) and acquired immunodeficiency syndrome (AIDS). Open trials on COVID-19 positive patients showed no improvement suggesting further investigation. Other protease inhibitors like nafamostat and griffithsin showed to inhibit glycosylation of spike protein of coronaviruses [31]. Hoffman et al., have clinically shown, camostat mesylate, a serine protease inhibitor which blocks 
TMPRSS2 activity could be considered a potential drug to treat COVID-19 [31]. Currently, this drug has been approved in Japan for human intake [32] [33].

\subsection{Host-Based}

Chloroquine and hydroxychloroquine that is in use since the last 70 years as front-line medication for malaria is the next drug candidate. They restrict the glycosylation of spike protein with the ACE2 receptor [34] [35]. It also increases the endosomal $\mathrm{pH}$ required for viral fusion to the cell thereby blocking the entry into the target cells [31]. Li and De Clerq have recently demonstrated that nitazoxanide and ribavirin show inhibitory action against SARS-CoV2 [29].

\subsection{Interferons, Antibodies and Corticosteroids}

Tocilizumab, an immune-suppressor used to treat rheumatoid arthritis and juvenile chronic arthritis is currently one of the popular drugs with some success [36]. It has been observed that critical COVID-19 patients experience a cytokine storm resulting in ARDS and subsequently death. Tocilizumab is a humanized monoclonal antibody against IL-6. Sallard et al., in their review have suggested the use of Type I interferon (IFN-I) as a possible treatment for COVID-19 patients [37]. IFN-I are a group of cytokines that have a broad range of antiviral activity in vitro and are currently under clinical trial for the treatment of MERS$\mathrm{CoV}$ and SARS-CoV patients. As there is a striking similarity between coronaviruses, IFN-I could be considered a potential drug and can be given to the patients in their early phase of infection [38]. Glucocorticoids, the primary medication in the previous endemic of SARS and MERS have also been listed for COVID-19 patients.

Beside available drugs, clinicians are using convalescent plasma to treat the novel coronavirus patients which means serum from recovered patients carrying vital antibodies is administered into newly infected patients. This neutralizes the virus thereby reducing the viral load and further complication. Though this modality was already in use during the Ebola outbreak (2014-15) but seems to be highly effective at the present condition. However, the amount of serum available currently is essentially very low as the number of new cases is far more than the number of recovered patients.

\section{Vaccines}

The development of a vaccine for COVID-19 at this time is the ultimate aim of all the SARS-CoV2 researchers throughout the world. With the knowledge and experience of past SARS and MERS outbreaks and recent mapping of SARSCoV2 virus [17], scientists have started clinical trials to deliver a successful candidate that could neutralize the deadly virus. According to WHO, there are about 83 potential candidate vaccines out of which 77 are in pre-clinical trials, 5 in phase 1 and 1 in phase 2 clinical trial (Table 3 ).

While there are effective traditional methods of vaccine development (live 
Table 3. Current status of vaccine development (Source: WHO).

\begin{tabular}{cccc}
\hline Developer & Country & Clinical Trial Phase & Strategy \\
\hline $\begin{array}{c}\text { CanSino Biological Inc./Beijing Institute of } \\
\text { Biotechnology }\end{array}$ & China & I and II & $\begin{array}{c}\text { Non-replicating } \\
\text { viral vector }\end{array}$ \\
$\begin{array}{c}\text { Beijing Institute of Biological Products/ } \\
\text { Wuhan Institute of Biological Products }\end{array}$ & China & I & Inactivated virus \\
Sinovac & China & I & Inactivated virus \\
University of Oxford & UK & I & $\begin{array}{c}\text { Non-Replicating } \\
\text { Viral Vector }\end{array}$ \\
BioNTech/Fosun Pharma/Pfizer & USA & I & RNA \\
Moderna/NIAID & USA & I & RNA \\
Inovio Pharmaceutical & USA & I & DNA \\
\hline
\end{tabular}

attenuated, inactivated, subunit and toxoids vaccines) relatively newer techniques (RNA or DNA based) have gained popularity as they are less expensive and rapid which is quite crucial in times of pandemic like this [39] [40] [41] [42]. Potential candidates for SARS-CoV2 vaccines include-the spike protein, the RBD, and the inactivated virus. The inactivated virus can be considered as the firstgeneration vaccines as they contain various structural proteins to induce neutralizing antibodies but the risk and safety concerns of investigators are higher. Incomplete or partial activation may pose a serious risk of infection or might even cause another SARS-like disease by inducing harmful inflammatory responses [43]. Recombinant vector-based vaccines expressing the S protein/RBD might produce neutralizing antibodies with a possible inhibition of viral binding and fusion to the host cell. According to a recent finding by Walls et al., SARS-CoV polyclonal antibodies inhibited the spike-mediated entry of SARS-CoV2 into VeroE6 cells [44]. With all potential and capabilities, the vaccine industry is working overtime to deliver and scale up a successful candidate.

\section{Acknowledgements}

The author would like to acknowledge Dr. Indu B. Maiti for his guidance and support. SA would like to thank Dr. Moonmoon Das for assistance in designing the phylogenetic tree.

\section{Conflicts of Interest}

The author declares no conflicts of interest regarding the publication of this paper.

\section{References}

[1] Lu, R., et al. (2020) Genomic Characterisation and Epidemiology of 2019 Novel Coronavirus: Implications for Virus Origins and Receptor Binding. The Lancet, 395, 565-574. https://doi.org/10.1016/S0140-6736(20)30251-8

[2] Zhu, N., et al. (2020) A Novel Coronavirus from Patients with Pneumonia in China, 2019. The New England Journal of Medicine, 382, 727-733.

https://doi.org/10.1056/NEJMoa2001017 
[3] Wu, F., et al. (2020) A New Coronavirus Associated with Human Respiratory Disease in China. Nature, 579, 265-269. https://doi.org/10.1038/s41586-020-2008-3

[4] Gorbalenya, A.E., et al. (2020) Severe Acute Respiratory Syndrome-Related Coronavirus: The Species and Its Viruses-A Statement of the Coronavirus Study Group.

[5] Jiang, S., et al. (2020) A Distinct Name Is Needed for the New Coronavirus. The Lancet, 395, 949. https://doi.org/10.1016/S0140-6736(20)30419-0

[6] Huang, C., et al. (2020) Clinical Features of Patients Infected with 2019 Novel Coronavirus in Wuhan, China. The Lancet, 395, 497-506. https://doi.org/10.1016/S0140-6736(20)30183-5

[7] Li, Q., et al. (2020) Early Transmission Dynamics in Wuhan, China, of Novel Coronavirus-Infected Pneumonia. The New England Journal of Medicine, 382, 1199 1207. https://doi.org/10.1056/NEJMoa2001316

[8] Valencia, D.N. (2020) Brief Review on COVID-19: The 2020 Pandemic Caused by SARS-CoV-2. Cureus, 12, e7386. https://doi.org/10.7759/cureus.7386

[9] Andersen, K.G., et al. (2020) The Proximal Origin of SARS-CoV-2. Nature Medicine, 26, 450-452. https://doi.org/10.1038/s41591-020-0820-9

[10] Lim, P.L., et al. (2004) Laboratory-Acquired Severe Acute Respiratory Syndrome. The New England Journal of Medicine, 350, 1740-1745. https://doi.org/10.1056/NEJMoa032565

[11] Corman, V.M., Muth, D., Niemeyer, D. and Drosten, C. (2018) Hosts and Sources of Endemic Human Coronaviruses. Advances in Virus Research, 100, 163-188. https://doi.org/10.1016/bs.aivir.2018.01.001

[12] Fehr, A.R. and Perlman, S. (2015) Coronaviruses: An Overview of Their Replication and Pathogenesis. Methods in Molecular Biology, 1282, 1-23.

https://doi.org/10.1007/978-1-4939-2438-7_1

[13] Chilvers, M.A., et al. (2001) The Effects of Coronavirus on Human Nasal Ciliated Respiratory Epithelium. European Respiratory Journal, 18, 965-970. https://doi.org/10.1183/09031936.01.00093001

[14] Jia, H.P., et al. (2005) ACE2 Receptor Expression and Severe Acute Respiratory Syndrome Coronavirus Infection Depend on Differentiation of Human Airway Epithelia. Journal of Virology, 79, 14614-14621. https://doi.org/10.1128/JVI.79.23.14614-14621.2005

[15] Wang, et al. (2020) Structural and Functional Basis of SARS-CoV-2 Entry by Using Human ACE2. Cell, 181, 894-904.e9. https://doi.org/10.1016/j.cell.2020.03.045

[16] Turner, A.J., Hiscox, J.A. and Hooper, N.M. (2004) ACE2: From Vasopeptidase to SARS Virus Receptor. Trends in Pharmacological Sciences, 25, 291-294. https://doi.org/10.1016/j.tips.2004.04.001

[17] Wrapp, D., et al. (2020) Cryo-EM Structure of the 2019-nCoV Spike in the Prefusion Conformation. Science, 367, 1260-1263. https://doi.org/10.1126/science.abb2507

[18] Rabi, F.A., et al. (2020) SARS-CoV-2 and Coronavirus Disease 2019: What We Know So Far. Pathogens, 9, pii: E231. https://doi.org/10.3390/pathogens9030231

[19] Liu, L., et al. (2011) Epithelial Cells Lining Salivary Gland Ducts Are Early Target Cells of Severe Acute Respiratory Syndrome Coronavirus Infection in the Upper Respiratory Tracts of Rhesus Macaques. Journal of Virology, 85, 4025-4030. https://doi.org/10.1128/JVI.02292-10

[20] Crackower, M.A., et al. (2002) Angiotensin-Converting Enzyme 2 Is an Essential Regulator of Heart Function. Nature, 417, 822-828. 
https://doi.org/10.1038/nature00786

[21] Tikellis, C., et al. (2003) Characterization of Renal Angiotensin-Converting Enzyme 2 in Diabetic Nephropathy. Hypertension, 41, 392-397. https://doi.org/10.1161/01.HYP.0000060689.38912.CB

[22] Zhang, Q., et al. (2018) Association of Angiotensin-Converting Enzyme 2 Gene Polymorphism and Enzymatic Activity with Essential Hypertension in Different Gender: A Case-Control Study. Medicine (Baltimore), 97, e12917. https://doi.org/10.1097/MD.0000000000012917

[23] Pan, F., et al. (2020) Time Course of Lung Changes on Chest CT during Recovery from 2019 Novel Coronavirus (COVID-19) Pneumonia. Radiology. https://doi.org/10.1148/radiol.2020200370

[24] Lauer, S.A., et al. (2020) The Incubation Period of Coronavirus Disease 2019 (COVID-19) from Publicly Reported Confirmed Cases: Estimation and Application. Annals of Internal Medicine, 172, 577-582. https://doi.org/10.7326/M20-0504

[25] Varia, M., et al. (2003) Investigation of a Nosocomial Outbreak of Severe Acute Respiratory Syndrome (SARS) in Toronto, Canada. CMAJ, 169, 285-292.

[26] Virlogeux, V., et al. (2016) Comparison of Incubation Period Distribution of Human Infections with MERS-CoV in South Korea and Saudi Arabia. Scientific Reports, 6, Article No. 35839. https://doi.org/10.1038/srep35839

[27] Lessler, J., et al. (2009) Incubation Periods of Acute Respiratory Viral Infections: A Systematic Review. The Lancet Infectious Diseases, 9, 291-300. https://doi.org/10.1016/S1473-3099(09)70069-6

[28] Cauchemez, S., et al. (2014) Middle East Respiratory Syndrome Coronavirus: Quantification of the Extent of the Epidemic, Surveillance Biases, and Transmissibility. The Lancet Infectious Diseases, 14, 50-56. https://doi.org/10.1016/S1473-3099(13)70304-9

[29] Li, G. and De Clercq, E. (2020) Therapeutic Options for the 2019 Novel Coronavirus (2019-nCoV). Nature Reviews Drug Discovery, 19, 149-150. https://doi.org/10.1038/d41573-020-00016-0

[30] Warren, T.K., et al. (2016) Therapeutic Efficacy of the Small Molecule GS-5734 against Ebola Virus in Rhesus Monkeys. Nature, 531, 381-385.

https://doi.org/10.1038/nature17180

[31] Wang, M., et al. (2020) Remdesivir and Chloroquine Effectively Inhibit the Recently Emerged Novel Coronavirus (2019-nCoV) in Vitro. Cell Research, 30, 269-271. https://doi.org/10.1038/s41422-020-0282-0

[32] Kawase, M., et al. (2012) Simultaneous Treatment of Human Bronchial Epithelial Cells with Serine and Cysteine Protease Inhibitors Prevents Severe Acute Respiratory Syndrome Coronavirus Entry. Journal of Virology, 86, 6537-6545. https://doi.org/10.1128/JVI.00094-12

[33] Zhou, Y., et al. (2015) Protease Inhibitors Targeting Coronavirus and Filovirus Entry. Antiviral Research, 116, 76-84. https://doi.org/10.1016/j.antiviral.2015.01.011

[34] Savarino, A., et al. (2006) New Insights into the Antiviral Effects of Chloroquine. The Lancet Infectious Diseases, 6, 67-69. https://doi.org/10.1016/S1473-3099(06)70361-9

[35] Yan, Y., et al. (2013) Anti-Malaria Drug Chloroquine Is Highly Effective in Treating Avian Influenza A H5N1 Virus Infection in an Animal Model. Cell Research, 23, 300-302. https://doi.org/10.1038/cr.2012.165

[36] Martinez, M.A. (2020) Compounds with Therapeutic Potential against Novel Res- 
piratory 2019 Coronavirus. Antimicrobial Agents and Chemotherapy, 64, pii: e00399-20. https://doi.org/10.1128/AAC.00399-20

[37] Sallard, E., et al. (2020) Type 1 Interferons as a Potential Treatment against COVID19. Antiviral Research, 178, Article ID: 104791. https://doi.org/10.1016/j.antiviral.2020.104791

[38] Siddiqi, H.K. and Mehra, M.R. (2020) COVID-19 Illness in Native and Immunosuppressed States: A Clinical-Therapeutic Staging Proposal. The Journal of Heart and Lung Transplantation, 39, 405-407.

[39] Chen, S.T., et al. (2017) Drug Repurposing and Therapeutic Anti-microRNA Predictions for Inhibition of Oxidized Low-Density Lipoprotein-Induced Vascular Smooth Muscle Cell-Associated Diseases. Journal of Bioinformatics and Computational Biology, 15, Article ID: 1650043. https://doi.org/10.1142/S0219720016500438

[40] Sahin, U., et al. (2017) Personalized RNA Mutanome Vaccines Mobilize Poly-Specific Therapeutic Immunity against Cancer. Nature, 547, 222-226. https://doi.org/10.1038/nature23003

[41] Sebastian, M., et al. (2019) A Phase I/IIa Study of the mRNA-Based Cancer Immunotherapy CV9201 in Patients with Stage IIIB/IV Non-Small Cell Lung Cancer. Cancer Immunology, Immunotherapy, 68, 799-812. https://doi.org/10.1007/s00262-019-02315-X

[42] Diken, M., Kranz, L.M., Kreiter, S. and Sahin, U. (2017) mRNA: A Versatile Molecule for Cancer Vaccines. Current Issues in Molecular Biology, 22, 113-128. https://doi.org/10.21775/cimb.022.113

[43] Wang, D. and Lu, J. (2004) Glycan Arrays Lead to the Discovery of Autoimmunogenic Activity of SARS-CoV. Physiological Genomics, 18, 245-248. https://doi.org/10.1152/physiolgenomics.00102.2004

[44] Walls, A.C., et al. (2020) Structure, Function, and Antigenicity of the SARS-CoV-2 Spike Glycoprotein. Cell, 181, 281-292. https://doi.org/10.1016/j.cell.2020.02.058 